\title{
OVER 'T SANSKRITVERS AAN 'T BEGIN DER INSCRIPTIE VAN DEN MINTO-STEEN.
}

Door H. KERN.

Onder de door Dr. Krom zoo zorgvuldig uitgegeven "OudJavaansche Oorkonden, Nagelaten Transscripties van wijlen Dr. J. L. A. BRANDES komt als $\mathrm{N}^{\circ}$ XXXI de groote inscriptie voor op een steen, afkomstig uit de residentie Soerabaja en indertijd door Raffles ten geschenke gezonden aan Lord Minto, destijds Goeverneur-Generaal van Bengalen. De steen staat thans op Minto-House in Schotland, waar hij niemands aandacht trok totdat het den ondergeteekende gelukte, dank zij de groote welwillendheid van wijlen Lord Elliot, een verwante der familie Minto, een fotografie der geheele inscriptie machtig te worden ${ }^{1}$. Het mag als voldoende bekend geacht worden dat de zoogenaamde vertaling der oorkonde in de Appendix op de History of Java van Raffles een litterarisch bedrog is, waarvan groote geleerden als Wilhelm von Humboldt en Lassen 't argeloos slachtoffer zijn geworden. Doch het is niet mijn plan hierover uit te weiden; ik wenschte alleen te spreken over het Sanskritvers dat aan den Oudjavaanschen inhoud der oorkonde voorafgaat.

Bij beschouwing van de fotografie ziet men dat verscheiden letters uitgewischt en andere niet duidelijk meer te onderscheiden zijn. De transscriptie van BRANDES, waarin de onzekere karakters onderstreept zijn, geeft het volgende te lezen:

1. ....... çiwamastu sarwwajagatah parahitaniratah bhawāntu . . ah

2. … doṣa praghātanāçāt sarwwatra sukhī. bhawatu lokah

Hoe het geheel geluid heeft, zou onmogelijk te zeggen zijn, ware het niet, dat Oorkonde XXX, afkomstig van Singasari, thans in 't Museum te Batavia, juist hetzelfde begin heeft, namelijk:

1 Bijzonderheden hieromtrent vindt men in Notulen Bat. Genootschap 1876, p. $98-100$. 
1. || o || awighnam astu || çiwam astu sarwwajagatah parahita(n)ratā bhawantu

2. bhūtaganāḥ ${ }^{1} \mid$ doṣāḥ prayāntu nāça(ṃ) || sarwwatra sukhī bhawatu lokaḥ \|o \|

De lezing van de strofe, een onberispelijke $\bar{A}$ ryā, laat niets te wenschen over, en luidt in vertaling: "Heêl zij de geheele wereld! Mogen de scharen der schepselen gaarne geneigd zijn om 't welzijn van anderen te bevorderen! Mogen (alle) euvelen verdwijnen! Moge de wereld overal gelukkig wezen!»

Het is wel opmerkelijk dat men denzelfden aanhef aantreft op twee Oorkonden, waarvan de eerste uitgevaardigd is in Çaka 837 (915 A. D.), de tweede in 846 (924 A. D.). Beide stukken zijn echter niet van denzelfden vorst: het eerste is een schenkingsoorkonde van koning Dakșottamabāhubajrapratipakșatișaya ${ }^{2}$; het tweede van een koning, een van wiens titels is Wijayaloka. Waarschijnlijk zijn beide praçasti's afkomstig uit dezelfde streek, doch in welke verhouding de twee genoemde vorsten tot elkander staan, is geheel onbekend. Als mapatih i hin o komt op den Minto-steen de naam voor van Çrī içānawikrama, die volgens een vermoeden van BRANDES geen andere is dan Mpu Sindok, die in Çaka 851, dus vijf jaar na de uitvaardiging van de praçasti van den Minto-steen, zelf als Mahārāja, grootkoning, optreedt ${ }^{3}$.

1 L. 'gaṇāḥ.

2 Zie Notulen Bat. Gen. 1887, p. 67.

3 Vgl. Brandes in Catalogus van 't Bat. Museum, p. 359-361. 